\title{
Acute bacterial nephritis. A descriptive study of an underdiagnosed entity
}

\section{Nefritis bacteriana aguda. Un estudio descriptivo de una entidad patológica subdiagnosticada}

\author{
Pedro Antonio Madero-Morales, ${ }^{1}$ iD Rigoberto Pallares-Méndez, ${ }^{1 *}$ Rodrigo Romero-Mata, ${ }^{1}$ \\ (iD Guillermo Vizcarra-Mata, ${ }^{1}$ iD Andrés Guillén-Lozoya. ${ }^{1}$
}

\section{Keywords:}

Acute bacterial

nephritis, acute

pyelonephritis, focal bacterial nephritis, multifocal bacterial nephritis, renal abscess.

\footnotetext{
Correspondencia: *Rigoberto Pallares-Méndez. Av. Madero y Gonzalitos S/N. 64460 Mitras Centro, Monterrey, Nuevo León. México. Correo electrónico: rigo_pallares@hotmail.com
}

\section{Abstract}

Background: Acute bacterial nephritis is an infectious process diagnosed through imaging studies. The clinical course of the disease has been shown to be more aggressive than acute pyelonephritis. It continues to be underdiagnosed, thus there are few studies on the entity in the literature.

Objective: To describe the clinical characteristics and imaging features of acute bacterial nephritis, as well as its clinical course.

Design: A descriptive, retrospective case series was conducted.

Materials and methods: Thirty-two cases of acute bacterial nephritis in patients admitted to the hospital within the time frame of 2009 to 2016 were reviewed. The patients' clinical characteristics upon admission were registered, as well as inpatient clinical progression, culture results, and antibiotic therapy response. The imaging studies were re-evaluated and the diagnostic consistency with either the focal or multifocal disease presentation was confirmed.

Results: Cases predominated in women $(n=29,90.62 \%)$ and the most frequently associated comorbidities were diabetes $(n=16,50 \%)$ and obesity $(n=9$, 28.25\%). The most important clinical findings upon admission were fever $(\mathrm{n}=15,46.87 \%)$ and leukocytosis $(\mathrm{n}=27,84.38 \%)$. Escherichia coli was the most commonly isolated bacterium (63.63\%). Both acute focal bacterial nephritis and acute multifocal bacterial nephritis were observed in $46.87 \%(\mathrm{n}=15)$ and $53.13 \%(n=17)$ of the patients, respectively. Imaging studies were required for all diagnoses.

Conclusion: Fever and leukocytosis are the main findings in acute bacterial nephritis. Imaging studies are necessary for making the diagnosis, given that acute pyelonephritis and acute bacterial nephritis cannot be clinically differentiated.

Citación: Citacion: Madero-Morales P. A., Pallares-Méndez R., Romero-Mata R., Vizcarra-Mata G., Guillén-Lozoya A. Acute bacterial nephritis. A descriptive study of an underdiagnosed entity. Rev Mex Urol. 2020;80(3):pp 1-10

\footnotetext{
${ }^{1}$ Universidad Autónoma de Nuevo León, Hospital Universitario "Dr. José Eleuterio González", Nuevo León, México
}

Recepción: 23 de noviembre de 2019 Aceptación: 09 de mayo de 2020

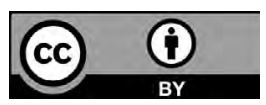




\section{Nefritis bacteriana aguda. Un estudio descriptivo de una entidad patológica... Madero-Morales P. A., et al.}

\section{Resumen}

Introducción: La nefritis bacteriana aguda (NBA) es un proceso infeccioso diagnosticado por medio de estudios de imagen. El curso clínico de la enfermedad ha mostrado ser más agresivo que la pielonefritis aguda y continúa siendo una entidad subdiagnosticada, para la cual sólo pocos estudios han sido reportados.

Objetivo: Describir las características clínicas e imagenológicas, cómo también el curso clínico de la enfermedad.

Diseño: Estudio descriptivo, retrospectivo, serie de casos.

Materiales y métodos: Se revisaron un total de 32 casos de nefritis bacteriana aguda admitidos a hospitalización entre 2009 y 2016. Se registraron las características clínicas al ingreso hospitalario, evolución clínica intrahospitalaria, resultados de cultivo y respuesta a tratamiento antibiótico. Los estudios de imagen fueron revalorados y comprobados para su compatibilidad diagnóstica con nefritis bacteriana aguda, en cualquiera de sus presentaciones; focal o multifocal.

Resultados: Se observó un predominio de mujeres ( $\mathrm{n}=29,90.62 \%)$; las comorbilidades más asociadas fueron diabetes $(n=16,50 \%)$ y obesidad ( $n=9,28.25 \%)$. Los hallazgos clínicos más importantes al ingreso fueron fiebre $(n=15,46.87 \%)$ y leucocitosis $(n=27,84.38 \%)$. Escherichia coli fue el agente bacteriano mayormente aislado (63.63\%). Se obser-

Palabras clave: Nefritis bacteriana aguda, pielonefritis aguda, nefritis bacteriana focal, nefritis bacteriana multifocal, absceso renal vó nefritis bacteriana focal y multifocal en $46.87 \%(\mathrm{n}=15)$ y $53.13 \%$ $(n=17)$, respectivamente. Todos los pacientes requirieron estudios de imagen para su diagnostico.

Conclusión: Los hallazgos principales en nefritis bacteriana aguda son fiebre y leucocitosis. Los estudios de imagen son necesarios para el diagnostico de nefritis bacteriana aguda dado que no es posible diferenciar clínicamente entre pielonefritis y nefritis bacteriana aguda.

\section{Introduction}

Acute bacterial nephritis (ABN), formerly known as acute lobar nephronia and first described by Rosenfield, ${ }^{(1)}$ is a bacterial infectious process of low prevalence that affects the renal parenchyma. It is caused by different infectious agents that reach the kidney through ascending invasion or hematogenous spread. ${ }^{(2)}$ Escheri- chia coli (E. coli) is the most commonly isolated etiologic agent. ${ }^{(1,3,4)}$ Hematogenous spread appears to be an important infection mechanism for $\mathrm{ABN}$, and wedge-shaped lesions on the renal parenchyma suggest bacterial emboli dissemination. ${ }^{(5)}$ 
Nefritis bacteriana aguda. Un estudio descriptivo de una entidad patológica... Madero-Morales P. A., et al.

$\mathrm{ABN}$ shares the same clinical features as acute pyelonephritis (APN) and both may present with fever, flank pain, pyuria, bacteriuria, and leukocytosis. . $3,4,6,7)^{\text {Therefore, imaging }}$ studies are needed to differentiate between $A B N$ and APN. The main sonographic findings in $\mathrm{ABN}$ are hypoechoic lesions with irregular, poorly defined margins, which may be associated with nephromegaly or perinephric fluid. Hyperechoic lesions may also be present. ${ }^{(8,9)} \mathrm{Ul}-$ trasound (US) sensitivity and specificity have been reported at $74 \%$ and $56.7 \%$, respectively. (10) Contrast computed tomography (CT) is the imaging study of choice, with a sensitivity of $90 \%$ and specificity of $86 \%,{ }^{(11)}$ but may be reserved for cases in which US is inconclusive. ${ }^{(1,12)}$

The majority of case series reported to date focus on pediatric patients, demonstrating a strong association between $\mathrm{ABN}$ and vesicoureteral reflux in $40 \%$ of cases. ${ }^{(2,7,13)}$ Acute inflammation, edema, and diffuse leukocyte infiltration are histopathologic findings in $\mathrm{ABN}$, as well as in APN. . $^{(4,6,14,15)}$

It is important to differentiate $\mathrm{ABN}$ from other infectious renal processes because a more aggressive and prolonged treatment is required and there is also a high risk of renal abscess progression. ${ }^{(15)}$ Few case series on ABN in adults are available, but at present, greater access to imaging studies has resulted in increased awareness and diagnosis of the disease.

\section{Materials and methods \\ Study design and definitions}

A descriptive, retrospective case series was conducted. Patients were searched in our database according to keywords related to ABN diagnosis. A total of 32 clinical files from 2009 to 2016 were reviewed for cases of $\mathrm{ABN}$ that met the inclusion criteria described below. Data regarding clinical features and laboratory findings were obtained from the clinical records. Complete blood count, blood chemistry, and urinalysis were carried out on all 32 patients. The imaging studies of each patient were reviewed. Once patients were admitted to the hospital and treatment was begun, hospital stay and clinical progression were assessed up to hospital discharge. The present study was classified as risk-free by the hospital ethics committee.

\section{Definitions}

$A B N$ was identified when the patient presented with fever, flank or abdominal pain, and abnormal urinalysis (pyuria and positive nitrite test), together with the following imaging criteria: 1) Contrast CT with wedge-shaped lesions, low contrast enhancement, and no cortical rim sign, 2) MRI with non-enhanced lesions on T1w or hypointense signal lesions on T2w, and 3) US with a reduced Doppler signal, associated with hypoechoic or hyperechoic wedge-shaped lesions. ${ }^{(8,16)} \mathrm{ABN}$ was categorized as acute focal bacterial nephritis (AFBN), when only one lobe was affected, and as acute multifocal bacterial nephritis (AMBN), when two or more lobes were affected.

Clinical features, such as obesity, were defined, according to the CDC criteria (BMI $\geq$ $30){ }^{(17)}$ diabetes was defined, according to the 2018 ADA criteria (fasting plasma glucose $\geq 126$ $\mathrm{mg} / \mathrm{dl}$ or random plasma glucose $\geq 200 \mathrm{mg} / \mathrm{dl}$ plus classic symptoms of hyperglycemia and/ or hyperglycemic crisis), ${ }^{(18)}$ and hypertension, in accordance with the JNC 8 report (blood pressure $\geq 140 / 90 \mathrm{mmHg}){ }^{(19)}$ Renal function 


\section{Nefritis bacteriana aguda. Un estudio descriptivo de una entidad patológica... Madero-Morales P. A., et al.}

was assessed utilizing the Cockcroft-Gault formula and chronic kidney disease (CKD) was considered when the patient presented with a GFR $<60 \mathrm{ml} / \mathrm{min}$.

\section{Exclusion criteria}

Patients whose imaging studies did not meet the definition or inclusion criteria for $A B N$ described above, or whose studies were inconclusive, were excluded, as were patients that presented with pyelonephritis or lower urinary tract infections.

\section{Imaging}

The imaging studies of all 32 patients were reassessed and checked for diagnostic consistency with $A B N$, in either the focal or multifocal presentation, ensuring that the patients were accurately diagnosed through the imaging study. The diagnosis was first checked in relation to the imaging report made by the radiologist, and we carried out further investigation to make sure that either focal or multifocal nephritis was present. Images were stored in Carestream
Vue PACS (Picture Archiving and Communication System) and GE Health Centricity PACS databases.

\section{Statistical analysis.}

The Kolmogorov-Smirnov and Shapiro-Wilk tests were performed to determine normality. All variables were collected and analyzed utilizing IBM SPSS version 22.0 software (Armonk, NY: IBM Corp).

\section{Results}

The clinical records and imaging studies of 32 patients with $A B N$ were evaluated. The majority of patients were women $(\mathrm{n}=29,90.62 \%)$ and mean patient age was 36.34 years ( $\mathrm{SD} \pm 13.23$ ). The associated comorbidities were diabetes $(\mathrm{n}=16,50 \%)$, obesity ( $\mathrm{n}=9,28.25 \%)$, hypertension $(\mathrm{n}=2,6.25 \%)$, and CKD $(\mathrm{n}=2,6.25 \%)$. Fever $(n=15,46.87 \%)$ and leukocytosis $(n=27$, $84.38 \%$ ) were the main clinical findings upon admission and the mean leukocyte count was $16.77 \mathrm{k} / \mu \mathrm{l} \pm 7.33$ (Table 1 ).

\section{Table 1. Clinical and demographic features}

\begin{tabular}{|c|c|c|}
\hline \multicolumn{3}{|l|}{ Demographic features } \\
\hline & Age; mean \pm SD & $35.6 \pm 14.5$ \\
\hline & $\operatorname{AFBN~n~(\% )~}$ & $15(46.87 \%)$ \\
\hline & AMBN n (\%) & $17(53.13 \%)$ \\
\hline & Women; n (\%) & $29(90.62 \%)$ \\
\hline & DM2; n (\%) & $16(50 \%)$ \\
\hline & HT; n (\%) & $2(6.25 \%)$ \\
\hline & CKD; n (\%) & $2(6.25 \%)$ \\
\hline & Smoking; n (\%) & $11(34.37 \%)$ \\
\hline
\end{tabular}

Continue... 


\begin{tabular}{lrr}
\hline & Alcohol; $\mathrm{n}(\%)$ & $8(25 \%)$ \\
\hline & Obesity; $\mathrm{n}(\%)$ & $9(28.25 \%)$ \\
\hline & & \\
\hline Clinical features upon admission & Temperature $\left({ }^{\circ} \mathrm{C}\right)$; mean \pm SD & $37.82 \pm 1.16$ \\
\hline & Leukocyte count; mean \pm SD & $16.77 \pm 7.33$ \\
\hline & Creatinine; mean \pm SD & $1.04 \pm 0.71$ \\
\hline
\end{tabular}

AFBN: acute focal bacterial nephritis; AMBN: acute multifocal bacterial nephritis; CKD: chronic kidney disease; DM2: diabetes mellitus type 2; HT: hypertension; SD: standard deviation.

The available CT, US, or magnetic resonance imaging (MRI) studies were reassessed for each patient. Only 5 patients (15.62\%) had an inconclusive US, requiring CT, and in those cases, the CT was utilized for the re-evaluation because it is a more sensitive imaging study. Abdominal contrast CT was performed on $59.38 \%(n=19)$ of the patients, ultrasonography on $37.5 \%(n=12)$, and MRI on $3.12 \%(n=1)$. One female patient had a single MRI study because she was pregnant. Imaging features required for diagnosis are specified in our inclusion criteria, examples of which are shown in Figure 1. Seventeen (53.13\%) patients presented with AMBN, whereas 15 (46.87\%) presented with AFBN.

\section{Figure 1. ABN imaging}
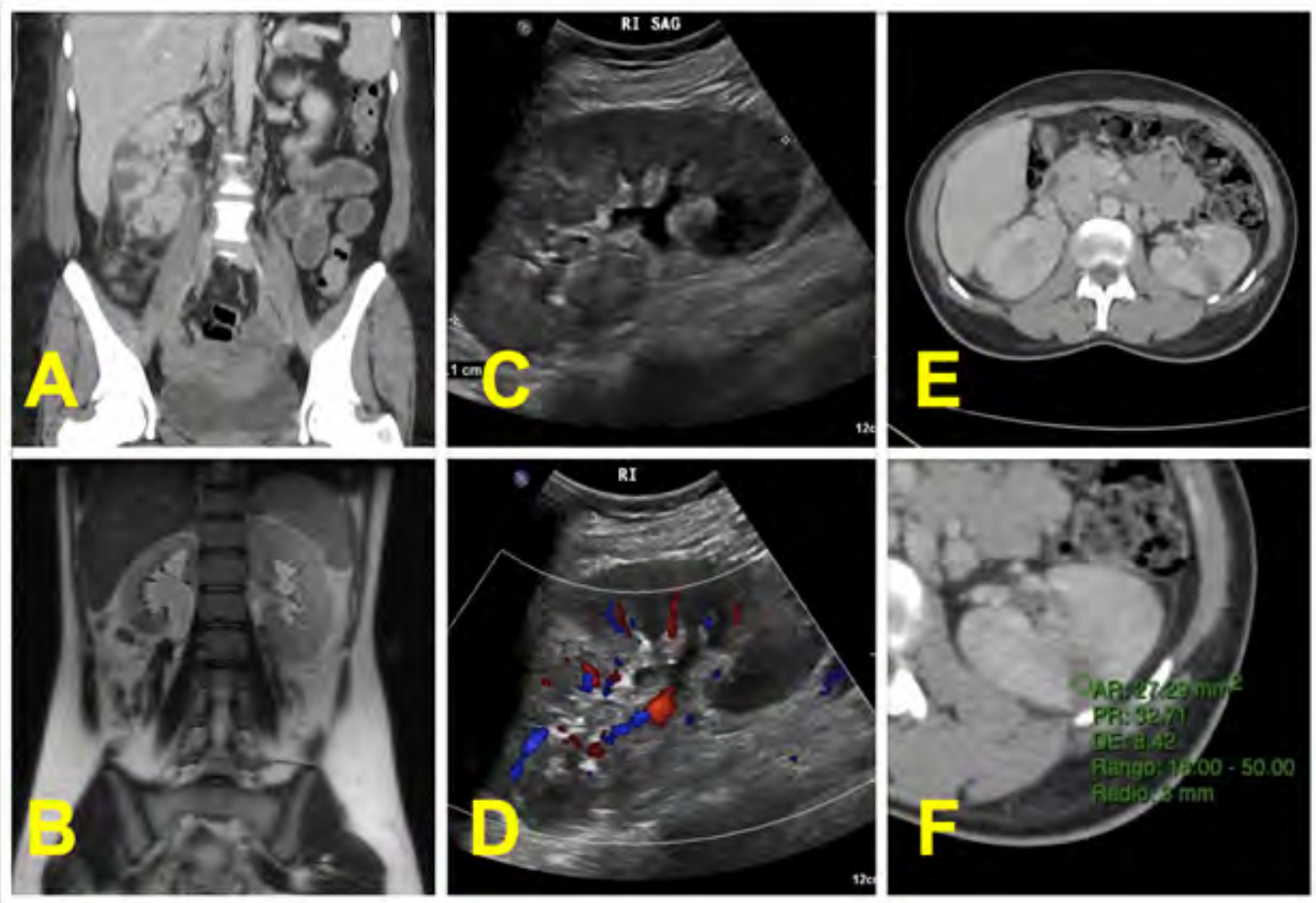

A) Contrast CT of right AMBN. B) T2w MRI of AFBN in the right lower pole. C) US of AFBN in the left lower pole. D) Doppler US showing no signal in the same patient. E). Contrast CT of left AFBN. F) Attenuation rate of previous image between 20-45 HUs (32.71 HUs). 
ABN: acute bacterial nephritis; CT: computed tomography; AFBN: acute focal bacterial nephritis; AMBN: acute multifocal bacterial nephritis; HUs: Hounsfield units: MRI: magnetic resonance imaging; US: ultrasound.

Intravenous antibiotics were used in all the cases. The most common combination in our study was a third-generation cephalosporin plus an aminoglycoside ( $\mathrm{n}=10,31.25 \%)$. Other antibiotic therapies included beta-lactams alone $(n=9,28.12 \%)$ and third-generation cephalosporins alone ( $\mathrm{n}=7,21.87 \%)$ (Table 2 ). Antibiotic therapy had to be escalated to carbapenems in $25 \%(n=8)$ of the patients, and a single case required nephrectomy (3.12\%).

Table 2. Association between clinical progression and treatment

\begin{tabular}{|l|r|}
\hline Hospital stay; mean \pm SD & $7.84 \pm 6.91$ \\
\hline Mortality; n (\%) & $2(6.25 \%)$ \\
\hline Progression to renal abscess; n (\%) & $3(9.37 \%)$ \\
\hline Treatment & $\mathrm{n}(\%)$ \\
\hline Beta-lactams & $9(28.12 \%)$ \\
\hline $\begin{array}{l}2^{\text {nd }} \text { generation cephalosporin }+ \\
\text { aminoglycoside }\end{array}$ & $1(3.12 \%)$ \\
\hline $3^{\text {rd }}$ generation cephalosporin & $7(21.87 \%)$ \\
\hline $\begin{array}{l}3^{\text {rd }} \text { generation cephalosporin }+ \\
\text { aminoglycoside }\end{array}$ & $10(31.25 \%)$ \\
\hline Aminoglycoside & $2(6.25 \%)$ \\
\hline Other & $3(9.37 \%)$ \\
\hline
\end{tabular}

SD: standard deviation.

Etiologic agents were isolated in urine cultures in $34.38 \%(\mathrm{n}=11)$ of the patients. $E$. coli $(\mathrm{n}=7,63.63 \%)$ was the most commonly isolated bacterium in the positive cultures, followed by coagulase-negative Staphylococcus $(\mathrm{n}=2,18.18 \%)$. The remaining isolated agents were $K$. pneumoniae, E. faecalis, $P$. aeruginosa, and Candida. Anaerobic blood culture was not routinely carried out.
Hospital stay was $7.84 \pm 6.91$ days and there were 2 deaths. Progression to renal abscess was observed in $9.37 \%(n=3)$ of the patients. The data is shown in Table 2.

\section{Discussion}

In the present case series report, we describe the clinical and imaging features, as well as the clinical course, of $A B N$, in either its focal or multifocal presentation. Imaging studies are mandatory for ABN diagnosis. Distinctive findings on contrast CT imaging are wedge-shaped hypodense lesions that exhibit no capsule and no contrast enhancement. Absence of the cortical rim sign helps distinguish between focal nephritis and renal infarction, ${ }^{(20,21)}$ and signs of perinephric inflammation, such as fat stranding, can also be observed. Density measurement between 0-20 Hounsfield Units (HUs) may help distinguish ABN from renal abscess, only when parenchymal necrosis tends to be liquid, because densities of kidney parenchyma and pus may overlap between 20-45 HUs. MRI, although not routinely used, shows hypointense $\mathrm{T} 2 \mathrm{w}$ lesions and low enhancement in T1w sequences. ${ }^{(20)}$ Sonography shows wedge-shaped lesions with a low or absent Doppler signal. Hypoechoic lesions are the most likely findings, but hyperechoic lesions may be present in some instances. ${ }^{(20,21)}$ Figure 1.

To the best of our knowledge, there are no specific guidelines for ABN, given that the etiologic agents related to the infectious process are the same as those in APN. The National Institute of Health and Care Excellence (NICE) guidelines for APN recommend 2nd and 3rd generation cephalosporin (cefuroxime or ceftriaxone), fluoroquinolones (ciprofloxacin), or aminogly- 
cosides (gentamicin, amikacin) as first choice IV treatment for the severely ill patient, and combinations are possible, depending on susceptibility. (22) Empiric treatment should be initiated, according to the most commonly found bacterium. A mid-stream urine sample should be taken for gram staining, culture, and antibiogram. In our case series, the most common antibiotic combination was a 3rd generation cephalosporin plus an aminoglycoside (ceftriaxone + amikacin), observed in $31.25 \%$ of the cases.

In a systematic review, Sieger et al. ${ }^{(20)}$ assessed 138 cases of ABN and reported features similar to those in our study. The cardinal clinical characteristics were fever, leukocytosis, and flank pain and E. coli was also the most commonly isolated etiologic agent. Those authors recommend conservative treatment, 2 weeks of oral antibiotic therapy after discharge, and then sonographic follow-up. Some of our patients were ineffectively treated before arriving at the emergency department, which could be related to the quantity of negative urine cultures reported in our case series (65.62\%). A positive urine culture is not mandatory for the diagnosis of urinary tract infections. (23) All of our patients had urinalyses that were consistent with urinary tract infections and the 32 cases of ABN were confirmed through imaging studies.

An advantage of our study was the description of clinical characteristics and imaging features of the two presentations of $\mathrm{ABN}$, an underdiagnosed entity. The recent interest in $\mathrm{ABN}$ has raised awareness in differentiating it from APN, considering it a midpoint between APN and renal abscess. ${ }^{(24)}$ Our patients were given IV antibiotics for $7.84 \pm 6.91$ days, concurring with the EAU guidelines, which recommend IV antibiotic treatment for 7 to 14 days. (25) Patients were discharged from the hospital after 48 hours of defervescence (Figure 2). No differences between the focal and multifocal presentations were observed.

Figure 2. Approach flowchart for ABN

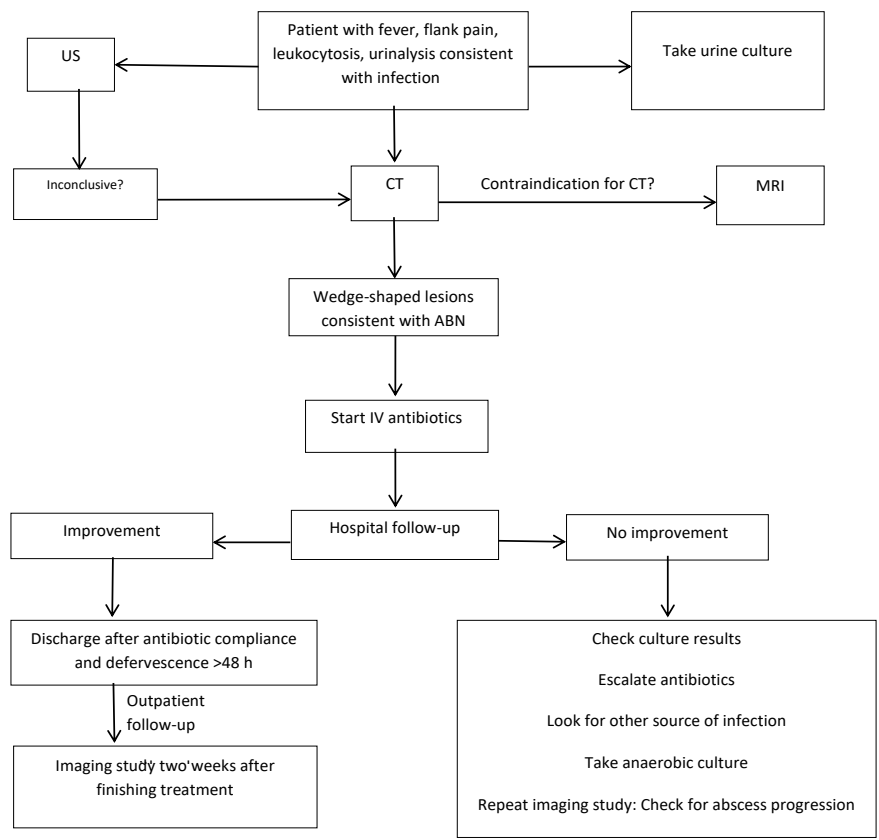

ABN: acute bacterial nephritis; CT: computed tomography; MRI: magnetic resonance imaging; US: ultrasound. 


\section{Nefritis bacteriana aguda. Un estudio descriptivo de una entidad patológica... Madero-Morales P. A., et al.}

\section{Conclusions}

The limitations of our study include its retrospective design, the small sample size, and the fact that not every patient had a standardized imaging study workup. Only 3 patients developed renal abscess, which hindered the progression analysis.

Our study showed that early and aggressive IV antibiotic therapy was effective in $A B N$ management. There should be high clinical suspicion of $A B N$ in all patients with presumptive APN, given that it presents with greater morbidity. Imaging assessment is crucial.

We reviewed 32 cases of $\mathrm{ABN}$ at our institution in the present analysis, and our results were similar to findings in other studies. . $1,6,8,20,26,27)$

We believe more studies showing that ABN is a different entity from APN are needed. The comparison of the two presentations has not been analyzed in depth, and their distinction can change patient prognosis and outcome.

\section{Financial disclosure}

No sponsorship of any kind was received in relation to this article.

\section{Conflict of interest}

The authors declare that they have no conflict of interest.

\section{References}

1. Rosenfield AT, Glickman MG, Taylor KJ, Crade M, Hodson J. Acute focal bacterial nephritis (acute lobar nephronia). Radiology. 1979;132(3):553-61. doi: 10.1148/132.3.553

2. Uehling DT, Hahnfeld LE, Scanlan KA. Urinary tract abnormalities in children with acute focal bacterial nephritis. BJU Int. 2000;85(7):885-8. doi: 10.1046/j.1464-410x.2000.00622.x

3. Cheng C-H, Tsau Y-K, Lin T-Y. Effective duration of antimicrobial therapy for the treatment of acute lobar nephronia. Pediatrics. 2006;117(1):e84-89. doi: 10.1542/peds.20050917

4. Cano Sch F, Strodthoff R P, Muñoz A O. Nefritis Aguda Focal: Caso Clínico. Revista chilena de pediatría. 2010;81(3):247-52. doi: 10.4067/ S0370-41062010000300008

5. Sieger N, Kyriazis I, Schaudinn A, Kallidonis P, Dietel A, Ganzer R, et al. Acute Focal Bacterial Nephritis Can Lead to Unnecessary Invasive Procedures: A Report of Three Cases. Urol Int. 2017;99(2):245-8. doi: 10.1159/000441955

6. Seidel T, Kuwertz-Bröking E, Kaczmarek S, Kirschstein M, Frosch M, Bulla M, et al. Acute focal bacterial nephritis in 25 children. Pediatr Nephrol. 2007;22(11):1897-901. doi: 10.1007/ s00467-007-0589-9

7. Downs SM. Technical report: urinary tract infections in febrile infants and young children. The Urinary Tract Subcommittee of the American Academy of Pediatrics Committee on Quality Improvement. Pediatrics. 1999;103(4):e54. doi: 10.1542/peds.103.4.e54

8. Rathaus V, Werner M. Acute focal nephritis: its true sonographic face. Isr Med Assoc J. 2007;9(10):729-31. 
9. Farmer KD, Gellett LR, Dubbins PA. The sonographic appearance of acute focal pyelonephritis 8 years' experience. Clin Radiol. 2002;57(6):483-7. doi: 10.1053/ crad.2002.0935

10. Majd M, Nussbaum Blask AR, Markle BM, Shalaby-Rana E, Pohl HG, Park JS, et al. Acute pyelonephritis: comparison of diagnosis with 99mTc-DMSA, SPECT, spiral CT, MR imaging, and power Doppler US in an experimental pig model. Radiology. 2001;218(1):101-8. doi: 10.1148/radiology.218.1.r01ja37101

11. Cheng C-H, Tsau Y-K, Hsu S-Y, Lee T-L. Effective ultrasonographic predictor for the diagnosis of acute lobar nephronia. Pediatr Infect Dis J. 2004;23(1):11-4. doi: 10.1097/01. inf.0000105202.57991.3e

12. Granados Molina A, Espino Hernández M, Gancedo Baranda A, Albillos Merino JC, Álvarez-Cortinas JF, Molina Amores C. Nefronía focal aguda bacteriana: diagnóstico, tratamiento y evolución. An Pediatr 2007;66(1):84-6. doi: 10.1157/13097366

13. Sugao H, Takiuchi H, Sakurai T. Acute focal bacterial nephritis and renal abscess associated with vesicoureteral reflux. Report of a case. Urol Int. 1988;43(4):253-6. doi: 10.1159/000281349

14. Dembry L-M, Andriole VT. Renal and perirenal abscesses. Infectious Disease Clinics. 1997;11(3):663-80. doi: 10.1016/S08915520(05)70379-2

15. Shimizu M, Katayama K, Kato E, Miyayama S, Sugata T, Ohta K. Evolution of acute focal bacterial nephritis into a renal abscess. Pediatr Nephrol. 2005;20(1):93-5. doi: 10.1007/ s00467-004-1646-2

16. Craig WD, Wagner BJ, Travis MD. Pyelonephritis: Radiologic-Pathologic Review. RadioGraphics. 2008;28(1):255-76. doi: $10.1148 /$ rg.281075171
17. Garrow JS, Webster J. Quetelet's index (W/ $\mathrm{H} 2)$ as a measure of fatness. Int J Obes. 1985;9(2):147-53.

18. Association AD. 2. Classification and Diagnosis of Diabetes: Standards of Medical Care in Diabetes-2018. Diabetes Care. 2018;41(Supplement 1):S13-27. doi: 10.2337/ dc18-S002

19. James PA, Oparil S, Carter BL, Cushman WC, Dennison-Himmelfarb C, Handler J, et al. 2014 Evidence-Based Guideline for the Management of High Blood Pressure in Adults: Report From the Panel Members Appointed to the Eighth Joint National Committee (JNC 8). JAMA. 2014;311(5):507-20. doi: 10.1001/ jama.2013.284427

20. Sieger N, Kyriazis I, Schaudinn A, Kallidonis P, Neuhaus J, Liatsikos EN, et al. Acute focal bacterial nephritis is associated with invasive diagnostic procedures - a cohort of 138 cases extracted through a systematic review. BMC Infect Dis. 2017;17(1):240. doi: 10.1186/ s12879-017-2336-6

21. Lee JK, McClennan BL, Melson GL, Stanley RJ. Acute focal bacterial nephritis: emphasis on gray scale sonography and computed tomography. AJR Am J Roentgenol. 1980;135(1):87-92. doi: 10.2214/ajr.135.1.87

22. National Institute for Clinical Excellence. Pyelonephritis (acute): antimicrobial prescribing. England: Public Health England; 2018. 26 p.

23. Watson JR, Sánchez PJ, Spencer JD, Cohen DM, Hains DS. Urinary Tract Infection and Antimicrobial Stewardship in the Emergency Department. Pediatr Emerg Care. 2018;34(2):93-5. doi: 10.1097/ PEC.0000000000000688

24. Janett S, Milani GP, Faré PB, Renzi S, Giannini O, Bianchetti MG, et al. Pyuria and microbiology 


\section{Nefritis bacteriana aguda. Un estudio descriptivo de una entidad patológica... Madero-Morales P. A., et al.}

in acute bacterial focal nephritis: a systematic review. Minerva med. 2019;110(3):232-7. doi: 10.23736/S0026-4806.19.06002-6

25. Bonkat G, Bartoletti RR, Bruyère F, Cai T, Geerlings SE, Köves B, et al. Urological Infections EAU Guidelines on urological infections. European Association of Urology; 2018.

26. Santacruz A, Collado MC, García-Valdés L, Segura MT, Martín-Lagos JA, Anjos T, et al. Gut microbiota composition is associated with body weight, weight gain and biochemical parameters in pregnant women. Br J Nutr. 2010;104(1):8392. doi: $10.1017 /$ S0007114510000176

27. Campos-Franco J, Macia C, Huelga E, DiazLouzao C, Gude F, Alende R, et al. Acute focal bacterial nephritis in a cohort of hospitalized adult patients with acute pyelonephritis. Assessment of risk factors and a predictive model. Eur J Intern Med. 2017;39:69-74. doi: 10.1016/j.ejim.2016.12.002 